\title{
PENYULUHAN HUKUM DALAM UPAYA PENINGKATAN KESADARAN HUKUM BERLALULINTAS MELALUI PEMAHAMAN TERHADAP ISI UNDANG-UNDANG NOMOR 22 TAHUN 2009 TENTANG LALU LINTAS DAN ANGKUTAN JALAN
}

\author{
Sudjana \\ Departemen Hukum Teknologi Informasi Komunikasi dan Kekayaan Intelektual, \\ Fakultas Hukum, Universitas Padjadjaran, email: sdjana@yahoo.com
}

\begin{abstract}
This study discusses the public understanding of the contents of Law No. 22 of 2009 regarding Traffic and Road Transportation. This is important, considering traffic and road transportation has an important role to realize the security, prosperity, order traffic and road transportation to support economic development. Methods Research method used is a normative juridical approach, Specifications descriptive analytical research, conducted research stage through the study of literature to examine the primary legal materials, secondary law, and tertiary legal materials. Data collected through the study of documents, and the method of data analysis is done through qualitative normative. The results showed that the understanding of the contents of Law No. 22 of 2009 regarding Traffic and Road Transportation is difficult to measure the level of legal awareness of citizens because there are other factors that affect the example of officials and oversight mechanisms in determining well.
\end{abstract}

Keywords: legal education, legal awareness, understanding, traffic and road transportation law.

\begin{abstract}
ABSTRAK
Kajian ini membahas mengenai pemahaman masyarakat terhadap isi Undang-undang No 22 Tahun 2009 Tentang Lalu Lintas dan Angkutan Jalan. Hal ini penting, mengingat lalu lintas dan Angkutan Jalan mempunyai peran penting guna mewujudkan keamanan, kesejahteraan, ketertiban berlalu lintas dan Angkutan Jalan untuk mendukung pembangunan ekonomi. Metode Penelitian yang digunakan adalah pendekatan yuridis normatif, Spesifikasi penelitian deskriptif analitis, Tahap penelitian dilakukan melalui studi kepustakaan untuk meneliti bahan hukum primer, bahan hukum sekunder, dan bahan hukum tersier. Teknik pengumpulan data dilakukan melalui studi dokumen, dan metode analisis data dilakukan melalui normatif kualitatif. Hasil kajian menunjukkan bahwa pemahaman terhadap isi Undang-undang No 22 Tahun 2009 Tentang Lalu Lintas dan Angkutan Jalan sulit untuk mengukur tingkat kesadaran hukum warga masyarakat karena ada faktor lain yang mempengaruhi yaitu teladan dari pejabat dan mekanisme pengawasan ikut menentukan juga.
\end{abstract}

Kata kunci : Penyuluhan hukum, kesadaran hukum, pemahaman, UU Lalulintas dan Angkutan Jalan.

\section{PENDAHULUAN}

Pembangunan hukum sebagai bagian integral dari sistem pembangunan nasional, secara strategis merupakan landasan dan menjadi perekat bidang pembangunan lainnya serta sebagai faktor integratif, dalam kehidupan berbangsa dan bernegara dalam bingkai NKRI melalui pembangunan sistem hukum nasional berdasarkan Pancasila dan Undang-Undang Dasar Negara Republik Indonesia tahun 1945. Pelaksanaan pembangunan hukum harus dilakukan secara komprehensif mencakup substansi hukum, kelembagaan hukum dan budaya hukum serta dibarengi dengan penegakan hukum secara tegas dan konsisten dengan tetap menjunjung tinggi hak asasi manusia, sehingga aktualisasi fungsi hukum sebagai sarana pembaharuan dan pembangunan, instrumen penyelesaian masalah secara adil serta sebagai pengatur perilaku masyarakat untuk menghormati hukum dapat tercapai ${ }^{1}$. Dalam upaya mewujudkan cita-cita luhur 
tersebut sudah tentu harus dilakukan melalui suatu sistem perencanaan pembangunan nasional yang terarah dan berkesinambungan secara terpadu. Pembangunan nasional tersebut diselenggarakan berdasarkan asas demokrasi dengan prinsip-prinsip kebersamaan, berkeadilan, berkelanjutan, berwawasan lingkungan, serta kemandirian dengan menjaga keseimbangan kemajuan dan kesatuan Nasional. Pembangunan bidang hukum harus diarahkan pada terwujudnya sistem pembangunan hukum nasional yang bersumber pada Pancasila dan Undang-Undang Dasar Negara Republik Indonesia tahun 1945, dalam rangka mewujudkan negara hukum serta penciptaan kehidupan masyarakat yang adil dan demokrasi ${ }^{2}$.

Berkat rahmat Tuhan Yang Maha Esa, Negara Kesatuan Republik Indonesia telah dianugerahi sebagai negara kepulauan yang terdiri atas beribu pulau, terletak memanjang di garis khatulistiwa, serta di antara dua benua dan dua samudera, mempunyai posisi dan peranan yang sangat penting dan strategis untuk mendukung pembangunan ekonomi, pemantapan integrasi nasional guna memperkukuh ketahanan nasional, serta menciptakan ketertiban dunia dan kehidupan berbangsa dan bernegara dalam rangka memajukan kesejahteraan umum sebagaimana diamanatkan oleh UUD Negara Republik Indonesia Tahun $1945^{3}$.

Lalu Lintas dan Angkutan Jalan mempunyai peran strategis dalam mendukung pembangunan dan integrasi nasional sebagai bagian dari upaya memajukan kesejahteraan umum sebagaimana diamanatkan oleh UUD Negara Republik Indonesia Tahun 1945. Sebagai bagian dari sistem transportasi nasional, lalu lintas dan angkutan jalan harus dikembangkan potensi dan perannya untuk mewujudkan keamanan, kesejahteraan, ketertiban berlalu lintas dan angkutan jalan dalam rangka mendukung pembangunan ekonomi dan pengembangan ilmu pengetahuan dan teknologi, otonomi daerah, serta akuntabilitas penyelenggaraan negara ${ }^{4}$.

Untuk menekan angka kecelakaan lalu lintas yang sangat tinggi, upaya ke depan diarahkan pada penanggulangan secara komprehensif yang mencakup upaya pembinaan, pencegahan, pengaturan, dan penegakan hukum. Upaya pembinaan tersebut dilakukan melalui peningkatan intensitas pendidikan berlalu lintas dan penyuluhan hukum serta pembinaan sumber daya manusia ${ }^{5}$. Penyuluhan hukum dilakukan juga untuk mewujudkan ketertiban berlalu lintas dan angkutan jalan dalam rangka meningkatkan kesadaran hukum melalui pemahaman UU No. 22 Tahun 2009 Tentang Lalu Lintas dan Angkutan.

Berdasarkan uraian tersebut, maka identifikasi masalahnya adalah:" Apakah Pemahaman terhadap isi Undang-Undang No. 22 Tahun 2009 Tentang Lalu Lintas dan Angkutan Jalan melalui penyuluhan hukum dapat meningkatkan kesadaran hukum berlalulintas."

\section{METODE PENELITIAN}

Metode penelitian digunakan pendekatan yuridis normatif, yaitu melakukan pendekatan terhadap permasalahan didasarkan pada kaidah atau norma hukum yang menjadi obyek pembahasan. Spesifikasi penelitian deskriptif analitis, yaitu menggambarkan obyek yang menjadi masalah kemudian dianalisis berdasarkan teori dan prinsif-prinsif hukum yang berlaku. Tahap penelitian dilakukan melalui studi kepustakaan untuk meneliti bahan hukum primer yaitu perundang-undangan nasional seperti UU No. 22 Tahun 2009 Tentang Lalu Lintas dan Angkutan Jalan dan dalam Peraturan Menteri Hukum dan HAM RI Nomor : M01.PR.08.10 Tahun 2007 Tentang Perubahan atas Peraturan Menteri Hukum dan Hak Asasi Manusia RI Nomor: M-01.PR.08.10 Tahun 2006 Tentang Pola Penyuluhan Hukum, bahan hukum sekunder yaitu pendapat para akhli berupa doktrin atau ajaran tentang hukum, dan bahan hukum tersier yaitu bahan hukum pendukung, seperti bahan digital dari internet. Teknik pengumpulan data dilakukan melalui studi dokumen, yang dilakukan dengan mengkaji dokumen-dokumen tentang hukum positif indonesia yang berkaitan dengan obyek pembahasan. Selanjutnya Metode analisis data dilakukan melalui normatif kualitatif yaitu mengkaji terhadap norma yang menjadi permasalahan kemudian dianalisis tanpa menggunakan rumus statistik.

\section{HASIL DAN PEMBAHASAN \\ Hubungan Penyuluhan hukum dengan Kesadaran hukum dan Budaya hukum}

Ketentuan yuridis tentang penyuluhan hukum diatur dalam Peraturan Menteri Hukum 
dan HAM RI Nomor : M-01.PR.08.10 Tahun 2007 tentang Perubahan atas Peraturan Menteri Hukum dan Hak Asasi Manusia RI Nomor : M01.PR.08.10 Tahun 2006 tentang Pola Penyuluhan Hukum. Latar belakang keluarnya peraturan menteri tersebut adalah dalam rangka mengembangkan budaya hukum di semua lapisan masyarakat agar dapat tercipta kesadaran dan kepatuhan hukum demi tegaknya supremasi hukum di Negara Kesatuan Republik Indonesia, perlu dilakukan penyuluhan hukum secara nasional dan agar pelaksanaan penyuluhan hukum secara nasional dapat berjalan secara tertib, terarah, dan terpadu, perlu didasarkan pada pola penyuluhan hukum.

Penyuluhan hukum adalah salah satu kegiatan penyebarluasan informasi dan pemahaman terhadap norma hukum dan peraturan perundang-undangan yang berlaku guna mewujudkan dan mengembangkan kesadaran hukum masyarakat sehingga tercipta budaya hukum dalam bentuk tertib dan taat atau patuh terhadap norma hukum dan peraturan perundang-undangan yang berlaku demi tegaknya supremasi hukum ${ }^{6}$. Sedangkan Kesadaran hukum masyarakat adalah nilai yang hidup dalam masyarakat dalam bentuk pemahaman dan ketaatan atau kepatuhan masyarakat terhadap norma hukum dan peraturan perundangundangan yang berlaku ${ }^{7}$. Soerjono Soekanto mengatakan bahwa kesadaran hukum adalah konsepsi abstrak dalam diri manusia tentang keserasian antara ketertiban dan ketentraman atau yang sepantasnya. Dengan demikian, Kesadaran hukum masyarakat merupakan output dari proses kegiatan penyuluhan hukum yang ditandai dengan adanya rasa untuk menghargai hukum, melalui praktek di lapangan, hanya cara atau teknik penyuluhan hukum yang bersifat komunikatif dan mampu menyentuh hati nurani masyarakat agar menghargai hukum, yang dapat berjalan efektif untuk menimbulkan kesadaran hukum masyarakat. Pilihan orang dalam berperilaku dan bersikap tindak sesuai dengan yang dikehendaki hukum sangat dipengaruhi oleh moral dan karakter masyarakat, dikarenakan hukum tidak pernah lepas dari lingkungan sosialnya ${ }^{8}$.

Penyuluhan Hukum diselenggarakan dengan tujuan mewujudkan kesadaran hukum masyarakat yang lebih baik sehingga setiap anggota masyarakat menyadari dan menghayati hak dan kewajibannya sebagai warga negara dan mewujudkan budaya hukum dalam sikap dan perilaku yang sadar, patuh, dan taat terhadap hukum serta menghormati hak asasi manusia ${ }^{9}$.

Lawrence M. Friedman mengatakan bahwa sistem hukum, ada beberapa komponen unsur hokum, ${ }^{10}$ yaitu 1) Sistem hukum mempunyai struktur. Sistem hukum terus berubah, namun bagian-bagian sistem itu berubah dalam kecepatan yang berbeda, dan setiap bagian berubah tidak secepat bagian tertentu lainnya; 2) Sistem hukum mempunyai substansi, yaitu berupa aturan, norma, dan pola perilaku nyata manusia yang berada dalam sistem itu; 3) Sistem hukum mempunyai komponen budaya hukum, yaitu sikap manusia terhadap hukum dan sistem hukum itu sendiri, seperti kepercayaan, nilai, pemikiran serta harapannya

Lawrence Friedman menjelaskan lebih lanjut bahwa budaya atau kultur hukum merupakan faktor nilai yang menimbulkan perbedaan dalam kehidupan hukum dalam masyarakat, sehingga kultur hukum merupakan sikap-sikap dan nilai-nilai yang dimiliki oleh masyarakat yang berhubungan dengan hukum dan lembaga-lembaganya, baik yang bersifat positif maupun negatif ${ }^{11}$.

Untuk mencapai peningkatan budaya hukum dan membentuk kesadaran hukum masyarakat, kegiatan penyuluhan hukum harus menetapkan arah kebijakan ${ }^{12}$ :

1) Melakukan edukasi dan pembudayaan hukum secara umum ditujukan kepada seluruh masyarakat. Bahwa banyaknya pelanggaran hukum yang terjadi dikarenakan lemahnya diseminasi dan penyuluhan hukum yang merupakan bagian dari tanggung jawab penyelenggara negara dan aparat penegak hukum.

2) Meningkatkan penggunaan media komunikasi yang lebih modern dalam pelaksanaan penyuluhan hukum yang dapat menunjang percepatan penyebaran, pengetahuan, pemahaman, dan penghayatan hukum.

3) Meningkatkan koordinasi dalam melaksanakan sosialisasi hukum dengan memanfaatkan partisipasi masyarakat aktif, media elektronik amupun non elektronik dan juga dengan memanfaatkan teknologi informasi.

4) Meningkatkan dan memperkaya metode pengembangan dan penyuluhan hukum 
untuk meningkatkan kesadaran hukum masyarakat dan hak asasi manusia secara terus menerus.

5) Memanfaatkan segala bentuk kampanye hukum baik langsung maupun tidak langsung, dengan menciptakan slogan-slogan hukum yang melekat di hati masyarakat sehingga masyarakat tergerak dengan sendirinya untuk meningkatkan budaya hukum.

6) Meningkatkan profesionalisme dan kemampuan tenaga penyuluh hukum baik dari substansi hukum, sosiologi serta pengenalan perilaku masyarakat setempat, sehingga komunikasi dalam menyampaikan materi hukum yang disuluh dapat lebih tepat, dipahami, diterima dengan baik oleh masyarakat.

7) Melalui kemampuan dan profesionalisme dalam melakukan penyuluhan hukum, agar pesan yang disampaikan kepada masyarakat tercapai dan diterima secara baik, maka harus melakukan langkah cerdas dalam penyuluhan hukum dengan memberikan rasa percaya masyarakat kepada tenaga penyuluh.

8) Law enforcement harus dibarengi dengan upaya preventif dalam bentuk sosialisasi produk- produk hukum karena hukum juga harus memberikan perlindungan kepada rakyat untuk memperoleh keadilan bukan untuk menyengsarakan. Oleh karena itu penyuluhan hukum harus mendapatkan perhatian yang serius.

Bernard Arief Sidharta, dalam hubungannya dengan kesadaran hukum dalam perspektif budaya hukum mengemukakan: "Kesadaran hukum adalah proses dalam kesadaran atau kejiwaan manusia yang di dalamnya berlangsung penilaian bahwa orang seharusnya bersikap dan bertindak dengan cara tertentu dalam situasi kemasyarakatan tertentu karena hal itu dirasakan adil dan perlu untuk terselenggaranya ketertiban masyarakat atau kondisi kemasyarakatan yang memungkinkan manusia menjalani kehidupan secara wajar sesuai dengan harkat dan martabatnya." 13 Sjachran Basah dalam hubungan ini mengemukakan tujuan pembinaan kesadaran hukum masyarakat adalah ${ }^{14}:(1)$. Meningkatkan kadar kesadaran hukum masyarakat dalam kehidupan bermasyarakat dan bernegara; (2) Menyadari hak dan kewajiban asasi warga negara di dalam negara hukum berdasarkan Pancasila; (3).Melibatkan diri dalam pembangunan dan memelihara hasil-hasil pembangunan.

Kesadaran hukum berbeda dengan kepatuhan hukum meskipun kedua-duanya dikonkritkan dalam sikap dan tindakan atau perikelakuan manusia dalam bermasyarakat. Menurut Max Weber, kepatuhan hukum berkaitan dengan paksaan yaitu sanksi, sehingga seseorang mentaati hukum karena takut terhadap sanksi yang dapat diterimanya. Sedangkan dalam kesadaran hukum, pentaatan timbul dengan sendirinya berdasarkan hati nurani tanpa paksaan.

Menurut H.C. Kelman, masalah kepatuhan hukum tersebut merupakan suatu derajat yang secara kualitatif dapat dibedakan pada tiga proses dasar ${ }^{15}$, yaitu:

a. Compliance

Suatu kepatuhan yang didasarkan pada harapan akan suatu imbalan dan usaha untuk menghindarkan diri dari hukuman yang mungkin dijatuhkan. Kepatuhan ini sama sekali tidak didasarkan pada suatu keyakinan pada tujuan kaedah hukum yang bersangkutan, dan lebih di dasarkan pada pengendalian dari pemegang kekuasaan. Sebagai akibatnya maka kepatuhan ada apabila ada pengawasan yang ketat terhadap pelaksanaan kaedah-kaedah hukum tersebut.

\section{b. Identification}

Terjadi apabila kepatuhan hukum ada bukan oleh karena nilai instrinsiknya, akan tetapi agar supaya keanggotaan kelompok tetap terjaga, serta ada hubungan baik dengan mereka yang memegang kekuasaan.

\section{c. Internalization}

Seseorang mematuhi hukum karena secara instrinsik kepatuhan tadi mempunyai imbalan. Isi kaedah tersebut sesuai dengan nilai-nilai yang semula dianutnya.

Dasar-dasar kepatuhan terhadap kaedah menurut R. Bierstedt adalah ${ }^{16}$ :

\section{a. Indoktrination}

Sebab pertama mengapa warga masyarakat mematuhi kaedah-kaedah hukum adalah karena dia diindoktrinir untuk berbuat demikian. Sejak kecil manusia telah dididik agar mematuhi kaedah-kaedah yang berlaku dalam masyarakat. Sebagaimana halnya dengan unsur-unsur kebudayaan lainnya, maka kaedah-kaedah telah ada waktu 
seseorang dilahirkan. Dan semula manusia menerimanya secara tidak sadar. Melalui proses sosialisasi manusia dididik untuk mengenal, mengetahui, serta mematuhi kaedah-kaedah tersebut.

\section{b. Habituation}

Oleh karena sejak kecil mengalami proses sosialisasi, maka lama kelamaan menjadi suatu kebiasaan untuk mematuhi kaedahkaedah yang berlaku. Memang pada mulanya sukar sekali untuk mematuhi kaedahkaedah tadi yang seolah-olah mengekang kebebasan. Akan tetapi apabila hal tersebut setiap hari ditemui, maka lama kelamaan menjadi suatu kebiasaan untuk mematuhinya terutama apabila manusia sudah mulai mengulangi perbuatan-perbuatannya dengan bentuk dan cara yang sama.

c. Utility

Pada dasarnya manusia mempunyai kecenderungan untuk hidup pantas dan teratur. Akan tetapi, apa yang pantas dan teratur untuk seseorang, belum tentu pantas dan teratur bagi orang lain. Oleh karena itu diperlukan suatu patokan tentang kepantasan dan keteraturan tersebut. Patokanpatokan tadi merupakan pedoman-pedoman tentang tingkah laku dan dinamakan kaedah. Dengan demikian, maka salah satu faktor yang menyebabkan orang taat pada kaedah adalah karena kegunaan dari pada kaedah tersebut. Manusia menyadari bahwa apabila dia hendak hidup pantas dan teratur maka diperlukan kaedah-kaedah.

\section{d. Group identification}

Salah satu sebab mengapa seseorang patuh pada kaedah, adalah karena kepatuhan tersebut merupakan salah satu sarana untuk mengadakan identifikasi dengan kelompok. Seseorang mematuhi kaedah-kaedah yang berlaku dalam kelompoknya bukan karena dia menganggap kelompoknya lebih dominan dari kelompok-kelompok lainnya, akan tetapi justru karena ingin mengadakan identifikasi dengan kelompoknya tadi.

Hoefnagles membedakan bermacammacam derajat kepatuhan terhadap hukum ${ }^{17}$ :

a. Seseorang bersikap tindak atau berperikelakuan sebagaimana diharapkan oleh hukum dan menyetujuinya sesuai dengan sistem nilai-nilai dari mereka yang berwenang. b. Seseorang berperikelakuan sebagaimana diharapkan oleh hukum dan menyetujuinya, akan tetapi tidak setuju dengan penilaian yang diberikan oleh yang berwenang terhadap hukum yang bersangkutan.

c. Seseorang mematuhi hukum, akan tetapi tidak setuju dengan kaidah-kaidah tersebut maupun pada nilai-nilai dari yang berwenang.

d. Seseorang tidak patuh pada hukum, akan tetapi menyetujuinya dan demikian juga terhadap nilai-nilai dari mereka yang berwenang.

e. Seseorang sama sekali tidak menyetujui ke semuanya dan dia pun tidak patuh pada hukum (melakukan protes).

Soerjono Soekanto membagi Faktorfaktor yang mempengaruhi kepatuhan hukum ke dalam tiga $\operatorname{tahapan}^{18}$, yaitu:

a. Tahap prakonvensional

Pada tahap prakonvensional ini manusia mematuhi hukum karena memusatkan perhatian pada akibat-akibat apabila hukum itu dilanggar. Proses yang terjadi pada tahap ini sebenarnya dapat dibagi dalam dua tahap lagi yakni tahap kekuatan fisik (seseorang mematuhi hukum agar terhindar dari penjatuhan hukuman atau sanksi negatif), dan tahap hedonistik (seseorang mematuhi hukum atau melanggar hukum untuk kepuasan dirinya sendiri);

b. Tahap Konvensional

Pada tahap ini tekanan diletakkan pada pengakuan, bahwa hukum berisikan aturan permainan dalam pergaulan hidup, yang senantiasa harus ditegakkan. Tetapi dalam kenyataannya, bukan hal ini yang selalu terjadi karena dalam tahap ini dikenal perbedaan antara dua tahap, yakni tahap interpersonal atau antar pribadi seseorang mematuhi hukum untuk memelihara hubungan baik dengan pihak-pihak lain dan untuk menyenangkan pihak lain tadi. Tahap hukum dan ketertiban (hukum dipatuhi karena penegak hukum mempunyai kekuasaan dan kekuasaan tersebut diakui);

c. Tahap Purna Konvensional

Dalam tahap ini, manusia mematuhi hukum karena dia mendukung prinsip-prinsip moral, terlepas dari apakah hukum itu didukung suatu kekuasaan dan wewenang atau tidak. Tahap ini biasanya dijabarkan 
dalam tahap-tahap kontrak sosial (seseorang mematuhi hukum karena hukum dianggap sebagai patokan yang dapat mempertahankan stabilitas dan memberikan kemungkinan pada terjadinya perubahan sosial), dan tahap etika universal (ditandai dengan kepatuhan hukum yang terutama disebabkan ada anggapan yang sangat kuat bahwa hukum merupakan refleksi dari etika)

Penyuluhan hukum merupakan bagian dari pembangunan hukum nasional, sedangkan pembangunan hukum nasional bagian dari pembangunan nasional. Kegiatan penyuluhan hukum merupakan salah satu sosialisasi untuk menggambarkan bagaimana itu keadilan tersebut ${ }^{19}$. Peranan hukum sebagai alat Pembangunan masyarakat sebagaimana dikemukakan oleh Roscoe Pound perlu ditempatkan pada persepsi yang disepakati bersama untuk memahami sifat, hakekat dan konsekuensi diterimanya suatu konsepsi. Apabila hukum diberi peranan sebagai sarana perubahan dan pembangunan, maka pemikiran ini membuktikan adanya kesadaran terhadap pengaruh timbal balik antara hukum dan masyarakat ${ }^{20}$.

Mochtar Kusumaatmadja mengemukakan "Teori Hukum Pembangunan" yang dibangun di atas teori kebudayaan Northrop, teori orientasi kebijakan (policy-oriented) dari Laswell dan Mc Dougal serta teori hukum pragmatis dari Roscoe Pound ${ }^{21}$, sebagai berikut: "Teori Hukum Mochtar (Teori Kebudayaan Northrop + Teori "Policy Oriented"nya Laswell dan Mc. Dougal) + Teori Hukum Pound minus konsepsi mekanisnya + disesuaikan kondisi Indonesia." Kelsey dan Herane mengemukakan falsafah penyuluhan adalah bekerja sama dengan masyarakat agar mereka dapat meningkatkan harkatnya sebagai manusia. Pendapat tersebut terkandung pengertian. Pertama, penyuluh harus bekerja sama dengan masayarakat. Kehadiran penyuluh bukan sebagai penentu atau pemaksa, tetapi ia harus mampu menciptakan suasana dialogis dengan masyarakat dan mampu menumbuhkan, menggerakkan, serta memelihara partisipasi masyarakat. Kedua, penyuluhan tidak menciptakan ketergantungan tetapi harus mampu mendorong semakin terciptanya kreativitas dan kemandirian masyarakat agar semakin memiliki kemampuan untuk berswakarsa, swadaya, swadana, dan swakelola bagi terselengaranya kegiatan-kegiatan guna tercapainya tujuan, harapan, dan keinginan masyarakat sasarannya. Ketiga, penyuluhan yang dilakukan harus selalu mengacu kepada terwujudnya kesejahteraan ekonomi masyarakat dan peningkatan harkatnya sebagai manusia ${ }^{22}$.

Adapun fungsi dari penyuluhan hukum adalah langkah pencegahan, langkah korektif, langkah pemeliharaan dan fungsi pengembangan. Pertama, penyuluhan sebagai langkah pencegahan (preventif), yakni mencegah timbulnya hak-hak negatif dan destruktif yang dapat mengakibatkan kerugian bagi masyarakat. Kedua, penyuluhan sebagai langkah korektif, yakni berfungsi sebagai koreksi terhadap hal yang telah ada, sehingga apabila terdapat suatu hal yang melanggar hukum dapat mengurangi dampak ataupun menghilangkan hal tersebut. Ketiga, penyuluhan sebagai langkah pemeliharaan (presevatif), yakni memberikan dorongan untuk menumbuhkan semangat supaya berpartisipasi dalam pembangunan hukum sesuai dengan kemampuan dan kedudukannya masing-masing. Keempat, penyuluhan sebagai fungsi pengembangan (developmental), yakni memberikan dorongan dan masukan terhadap suatu hal agar masyarakat dapat lebih mandiri dan tidak tergantung ataupun mengandalkan pihak lain ${ }^{23}$.

Visi dan misi dari kegiatan penyuluhan hukum ini adalah agar dilaksanakannya aturanaturan hukum tanpa menyebabkan perasaan takut akan sanksi hukum melainkan patuhnya mereka pada aturan hukum dikarenakan adanya kesadaran dan penghargaan terhadap hukum.

Di dalam menyelenggarakan kegiatan penyuluhan hukum ada baiknya bila materi hukum yang akan disuluhkan dibuat skala prioritas yang didasarkan pada pengetahuan, pemahaman, dan penghayatan terhadap materi hukum, sehingga untuk materi hukum yang sangat penting untuk kehidupan berbangsa, bernegara dan bermasyarakat dapat segera disuluhkan agar segera dipahami dan dihayati oleh masyarakat. Hal ini perlu diinventarisir dan ditelaah berdasarkan pertimbangan yang komprehensif serta didasarkan pada hasil evaluasi, peta permasalahan hukum, kepentingan negara dan kebutuhan masyarakat ${ }^{24}$.

\section{Substansi Undang-undang Lalu Lintas dan Angkutan Jalan}


Lalu Lintas dan Angkutan Jalan merupakan faktor vital dalam kehidupan bermasyarakat baik dikaji dari segi dari ekonomi, sosial, dan hukum karena itu penting untuk dijadikan materi penyuluhan hukum. Dalam kaitan ini, penyuluh perlu menjelaskan berbagai ketentuan terkait lalu lintas dan angkutan jalan apa saja permasalahan yang timbul dan apa yang seharusnya dilakukan oleh pengguna jalan untuk mengatasinya. Lalu lintas dan angkutan jalan adalah satu kesatuan sistem yang terdiri atas lalu lintas, angkutan jalan, jaringan lalu lintas dan angkutan jalan, prasarana lalu lintas dan angkutan jalan, kendaraan, pengemudi, pengguna jalan, serta pengelolaannya. Lalu lintas adalah gerak kendaraan dan orang di ruang lalu lintas jalan. Angkutan adalah perpindahan orang dan/atau barang dari satu tempat ke tempat lain dengan menggunakan kendaraan di ruang lalu lintas jalan.

Tabel 1. Sistematika Undang-undang No 22 Tahun 2009 Tentang Lalu Lintas Dan Angkutan Jalan terdiri dari 326 Pasal, XXII Bab.

\begin{tabular}{|c|c|c|}
\hline BAB I & : & KETENTUAN UMUM (Pasal 1) \\
\hline BAB II & : & ASAS DAN TUJUAN (Pasal 2 sd 3) \\
\hline BAB III & : & RUANG LINGKUP KEBERLAKUAN UNDANG-UNDANG (Pasal 4) \\
\hline BAB IV & : & PEMBINAAN (Pasal 5 sd 6) \\
\hline BAB V & : & PENYELENGGARAAN (Pasal 7 sd 13) \\
\hline BAB VI & $:$ & JARINGAN LALU LINTAS DAN ANGKUTAN JALAN (Pasal $14 \mathrm{sd} 46$ ) \\
\hline BAB VII & : & KENDARAAN (Pasal 47 sd 76) \\
\hline BAB VIII & : & PENGEMUDI (Pasal 77 sd 92) \\
\hline BAB IX & : & LALU LINTAS (Pasal 93 sd 136) \\
\hline BAB X & : & ANGKUTAN (Pasal 137 sd 199) \\
\hline BAB XI & : & $\begin{array}{l}\text { KEAMANAN DAN KESELAMATAN LALU LINTAS DAN ANGKUTAN } \\
\text { JALAN (Pasal } 200 \mathrm{sd} 208 \text { ) }\end{array}$ \\
\hline BAB XII & $:$ & DAMPAK LINGKUNGAN (Pasal 209 sd 218) \\
\hline BAB XIII & : & 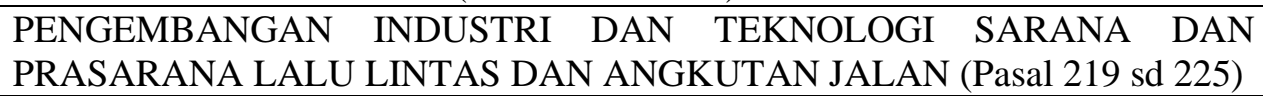 \\
\hline BAB XIV & : & KECELAKAAN LALU LINTAS (Pasal 226 sd 241) \\
\hline BAB XV & & $\begin{array}{l}\text { PERLAKUAN KHUSUS BAGI PENYANDANG CACAT, MANUSIA USIA } \\
\text { LANJUT, ANAK-ANAK, WANITA HAMIL, DAN ORANG SAKIT (Pasal } \\
242 \mathrm{sd} 244 \text { ) }\end{array}$ \\
\hline BAB XVI & : & 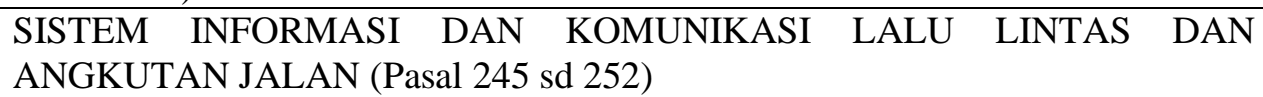 \\
\hline BAB XVII & : & SUMBER DAYA MANUSIA (Pasal 253 sd 255) \\
\hline BAB XVIII & : & PERAN SERTA MASYARAKAT (Pasal 256 sd 258) \\
\hline BAB XIX & & $\begin{array}{l}\text { PENYIDIKAN DAN PENINDAKAN PELANGGARAN LALU LINTAS DAN } \\
\text { ANGKUTAN JALAN (Pasal } 259 \text { sd 272) }\end{array}$ \\
\hline $\mathrm{BAB} \mathrm{XX}$ & & KETENTUAN PIDANA (Pasal 273 sd 317) \\
\hline BAB XXI & & KETENTUAN PERALIHAN (Pasal 318 sd 319 \\
\hline BAB XXII & & KETENTUAN PENUTUP (Pasal 320 sd 326) \\
\hline
\end{tabular}

Pemahaman isi UU No. 22 Tahun 2009 Tentang Lalu Lintas dan Angkutan Jalan melalui Penyuluhan Hukum dihubungkan dengan Kesadaran Hukum Berlalulintas

Benjamin S. Bloom, ${ }^{25}$ mengatakan bahwa pemahaman (Comprehension) adalah kemampuan seseorang untuk mengerti atau memahami sesuatu setelah sesuatu itu diketahui dan diingat. Dengan kata lain, memahami adalah mengerti tentang sesuatu dan dapat melihatnya dari berbagai segi ${ }^{26}$.
Menurut Daryanto kemampuan pemahaman berdasarkan tingkat kepekaan dan derajat penyerapan materi dapat dijabarkan ke dalam tiga tingkatan ${ }^{27}$, yaitu:

a. Menerjemahkan (translation)

Pengertian menerjemahkan dapat diartikan sebagai pengalihan arti dari bahasa yang satu ke dalam bahasa yang lain. Dapat juga dari konsepsi abstrak menjadi suatu model simbolik untuk mempermudah orang mempelajarinya. 
b. Menafsirkan (interpretation)

Kemampuan ini lebih luas daripada menerjemahkan, ini adalah kemampuan untuk mengenal dan memahami. Menafsirkan dapat dilakukan dengan cara menghubungkan pengetahuan lalu dengan pengetahuan yang diperoleh berikutnya, menghubungkan antara grafik dengan kondisi yang dijabarkan sebenarnya, serta membedakan yang pokok dan tidak pokok dalam pembahasan.

c. Mengekstrapolasi (extrapolation)

Ekstrapolasi menuntut kemampuan intelektual yang lebih tinggi karena seseorang dituntut untuk dapat melihat sesuatu dibalik yang tertulis. Membuat ramalan tentang konsekuensi atau memperluas persepsi dalam arti waktu, dimensi, kasus, ataupun masalahnya.

Kaitan dengan penyuluhan hukum tingkatan ke tiga "mengekstrapolasi" erat dengan peningkatan kesadaran hukum meskipun ada faktor lain yang mempengaruhinya, karena masyarakat yang diberikan pemahaman tentang UU Lalulintas dan Angkutan jalan dapat melihat dibalik UU tersebut ada tujuan hukum yang hendak dicapai yaitu kepastian, keadilan dan kemanfaatan.

Ranah kognitif berkenaan dengan hasil belajar intelektual yang berhubungan dengan ingatan atau pengenalan terhadap pengetahuan dan informasi serta pengembangan keterampilan intelektual. Menurut Taksonomi Bloom (penggolongan) ranah kognitif ada enam tingkatan $^{28}$, yaitu

a. Pengetahuan, merupakan tingkat terendah dari ranah kognitif. Menekankan pada proses mental dalam mengingat dan mengungkapkan kembali informasi yang telah siswa peroleh secara tepat sesuai dengan apa yang telah mereka peroleh sebelumnya. Informasi dimaksud berkaitan dengan simbol-simbol, terminologi dan peristilahan, fakta-fakta, keterampilan dan prinsip-prinsip.

b. Pemahaman (Comprehension), berisikan kemampuan untuk memaknai dengan tepat apa yang telah dipelajari tanpa harus menerapkannya.

c. Aplikasi (Application), pada tingkat ini seseorang memiliki kemampuan untuk menerapkan gagasan, prosedur, metode, rumus, teori sesuai dengan situasi konkrit. d. Analisis (Analysis), seseorang akan mampu menganalisis informasi yang masuk dan membagi-bagi atau menstrukturkan informasi ke dalam bagian yang lebih kecil untuk mengenali pola atau hubungannya, dan mampu mengenali serta membedakan faktor penyebab dan akibat dari sebuah kondisi yang rumit.

e. Sintesis (Synthesis), seseorang di tingkat sintesa akan mampu menjelaskan struktur atau pola dari sebuah kondisi yang sebelumnya tidak terlihat, dan mampu mengenali data atau informasi yang harus didapat untuk menghasilkan solusi yang dibutuhkan.

f. Evaluasi (Evaluation), kemampuan untuk memberikan penilaian berupa solusi, gagasan, metodologi dengan menggunakan kriteria yang cocok atau standar yang ada untuk memastikan nilai efektivitas atau manfaatnya. Ranah afektif berkenaan dengan sikap, terdiri dari lima aspek yaitu penerimaan, jawaban atau reaksi, penilaian, organisasi dan internalisasi. Sedangkan ranah psikomotor berkenaan dengan hasil belajar keterampilan dan kemampuan bertindak, ada enam aspek yakni gerakan reflek, keterampilan gerakan dasar, kemampuan perseptual, keharmonisan atau ketepatan, gerakan keterampilan kompleks, dan gerakan ekspresif dan interpretatif ${ }^{29}$.

Berdasarkan taksonomi Bloom, maka pemahaman berada dalam taraf kemampuan untuk memaknai dengan tepat apa yang telah dipelajari tanpa harus menerapkannya. Dengan demikian, pemahaman setelah mendapat penyuluhan hukum sulit untuk mengukur tingkat kesadaran hukum karena ada kemungkinan meskipun melakukan sesuai dengan ketentuan yang berlaku, tetapi dipengaruhi faktor lain.

Paul Sholten yang dikutip oleh Soerjono Soekanto mengatakan bahwa "kesadaran hukum sebenarnya merupakan kesadaran atau nilai-nilai yang terdapat di dalam diri manusia tentang hukum yang ada atau tentang hukum yang diharapkan ada." Secara sederhana nilainilai tersebut pada hakekatnya didasarkan pada rasa susila dan rasa keadilan dari individu yang melakukan interaksi sosial ${ }^{30}$. Dengan demikian, kesadaran hukum merupakan pentaatan tanpa paksaan sehingga metode penyuluhan hukum juga harus bersifat ajakan bukan paksaan. 
Metode penyuluhan hukum dilakukan secara langsung (tatap muka) atau tidak langsung (melalui media elektronik atau cetak), melalui pendekatan:

a. persuasif yakni penyuluh hukum dalam melaksanakan tugasnya harus mampu meyakinkan masyarakat yang disuluh, sehingga mereka merasa tertarik dan menaruh perhatian serta minat terhadap halhal yang disampaikan oleh penyuluh;

b. edukatif yakni penyuluh hukum harus bersikap dan berperilaku sebagai pendidik yang dengan penuh kesabaran dan ketekunan membimbing masyarakat yang disuluh ke arah tujuan penyuluhan hukum;

c. komunikatif yakni penyuluh hukum harus mampu berkomunikasi dan menciptakan iklim serta suasana sedemikian rupa sehingga tercipta suatu pembicaraan yang bersifat akrab, terbuka dan timbal balik; dan

d. akomodatif yakni penyuluh hukum harus mampu mengakomodasikan menampung dan memberikan jalan pemecahannya dengan bahasa yang mudah dimengerti dan dipahami terhadap permasalahan-permasalahan hukum yang diajukan oleh masyarakat.

Penyuluhan Hukum secara langsung dapat diselenggarakan dalam bentuk : a) ceramah; b) diskusi; c) temu sadar hukum; d) pameran; e) simulasi; f) lomba kadarkum; g) konsultasi hukum; h) bantuan hukum; dan/atau i) dalam bentuk lain. Sedangkan Penyuluhan Hukum tidak langsung dapat diselenggarakan dalam bentuk : a) dialog interaktif; b) wawancara radio; c) pentas panggung; d) sandiwara; e) sinetron; f) fragmen; g) film; h) spanduk; i) poster; j) brosur; k) leaflet; 1) booklet; m) billboard; n) surat kabar; o) majalah; p) running text; q) filler; dan/atau r) dalam bentuk lain.

Penyuluhan Hukum dilakukan oleh tenaga fungsional penyuluh hukum dan/atau orang yang mempunyai pengetahuan dan keahlian di bidang hukum dan mampu menyampaikan informasi atau penjelasan tentang materi yang disuluhkan, secara jelas dan benar, kepada masyarakat yang disuluh. Pelaksanaan penyuluhan hukum di lingkungan Departemen Hukum dan Hak Asasi Manusia, dikoordinasikan oleh Pusat Penyuluhan Hukum Badan Pembinaan Hukum Nasional. Badan Pembinaan Hukum Nasional dalam melaksanakan penyuluhan hukum dapat melakukan kerja sama dengan instansi terkait atau organisasi kemasyarakatan di tingkat pusat. Bentuk kerjasama dapat dituangkan dalam peraturan bersama, kesepakatan bersama atau instrumen hukum lainnya.

Kelompok sasaran (warga masyarakat) dalam penyuluhan hukum merupakan faktor penting untuk lebih diperhatikan tanpa mengurangi pentingnya penyuluh hukum, materi hukum (substansi) yang akan disuluhkan, dan metode penyuluhan hukum itu sendiri, karena pada akhirnya warga masyarakat tersebut yang diharapkan akan adanya perubahan perikelakuan hukum menuju tingkat kesadaran hukum yang lebih baik.

Hasil survey yang dilakukan oleh Tabloit Otomotif terhadap jumlah responden 10.045 orang terkait dengan alasan mengapa tidak yakin UU Nomor 22 Tahun 2009 dapat memperbaiki masalah, seperti pada tabel 2.

Tabel 2. Hasil Survey Tabloit Otomotif tentang UU Nomor 22 Tahun 2009

\begin{tabular}{lc}
\hline \multicolumn{1}{c}{ Alasan } & Jumlah $(\%)$ \\
\hline Kesadaran/disiplin masalah & 30 \\
\hline Volume kendaraan terus bertambah/sudah banyak & 10 \\
\hline Mental aparat kurang baik & 8 \\
\hline Pelaksanaan belum efektif & 6 \\
\hline Infrastruktur kurang (jalan, rambu, fasilitas) & 6 \\
\hline Jadi lebih macet & 6 \\
\hline Tergantung kesadaran masyarakat & 5
\end{tabular}

Sumber : Edy Halomoan Gurnin, dalam http://www. bantuanhukum.or.id/ web/implementasi-undangundang-nomor-22-tahun-2009-tentang-lalu-lintas-dan-angkutan-jalan-raya/

\footnotetext{
Berdasarkan data tersebut masalah menempati posisi tertinggi berkaitan dengan kesadaran atau disiplin (masyarakat) implementasi UU No. 22 Tahun 2009, karena
} 
itu fokus perhatian pada warga masyarakat 22 Tahun 2009, dari sekian banyak ketentuan dalam penyuluhan hukum UU tersebut merupa- yang ada, beberapa pasal yang mendapatkan kan priotitas utama untuk lebih diperhatikan. respon beragam dan menjadi perdebatan di Selanjutnya, berkaitan dengan materi UU No. masyarakat ${ }^{31}$ adalah seperti pada tabel 3.

Tabel 3. Respon Masyarakat terhadap UU No. 2 Tahun 2009

\begin{tabular}{|c|c|c|}
\hline Ketentuan & Isi & Catatan \\
\hline 107 Ayat (2) & $\begin{array}{l}\text { Pengemudi Sepeda Motor selain } \\
\text { mematuhi ketentuan sebagaimana } \\
\text { dimaksud pada Ayat (1) wajib menya- } \\
\text { lakan lampu utama pada siang hari }\end{array}$ & $\begin{array}{l}\text { Jika alasannya adalah untuk keselamatan, } \\
\text { maka harus diyakinkan hubungan langsung } \\
\text { lampu dengan keselamatan pengendara. } \\
\text { Selain itu dukungan data-data mengenai } \\
\text { penyebab kecelakaan di jalan raya }\end{array}$ \\
\hline 112 Ayat (3) & $\begin{array}{l}\text { Pada persimpangan Jalan yang dilengkapi } \\
\text { Alat Pemberi Isyarat Lalu Lintas, } \\
\text { Pengemudi Kendaraan dilarang langsung } \\
\text { berbelok kiri, kecuali ditentukan lain oleh } \\
\text { Rambu Lalu Lintas atau Alat Pemberi } \\
\text { Isyarat Lalu Lintas }\end{array}$ & $\begin{array}{l}\text { Seberapa banyak sarana yang telah } \\
\text { disediakan }\end{array}$ \\
\hline 273 Ayat (1) & $\begin{array}{l}\text { Setiap penyelenggara Jalan yang tidak } \\
\text { dengan segera dan patut memperbaiki } \\
\text { Jalan yang rusak yang mengakibatkan } \\
\text { Kecelakaan Lalu Lintas sebagaimana } \\
\text { dimaksud dalam Pasal } 24 \text { Ayat (1) } \\
\text { sehingga menimbulkan korban luka } \\
\text { ringan dan/atau kerusakan Kendaraan } \\
\text { dan/atau barang dipidana dengan penjara } \\
\text { paling lama } 6 \text { (enam) bulan atau denda } \\
\text { paling banyak Rp. 12.000.000,00 (dua } \\
\text { belas juta rupiah }\end{array}$ & $\begin{array}{l}\text { Kementerian PU memper- masalahkan } \\
\text { pasal pemida naan penyelenggara jalan } \\
\text { yang memang secara hukum tidak } \\
\text { berdasarkan konsep yang kuat. Fungsi } \\
\text { pemerintahan, termasuk penyeleng-garaan } \\
\text { jalan, pada prinsipnya adalah pelaksanaan } \\
\text { undang- undang. Wajarkah aturan } \\
\text { perundangan yang memi- danakan } \\
\text { pelaksana undang-undang }\end{array}$ \\
\hline Bab XIII & $\begin{array}{l}\text { pengembangan industri dan teknologi } \\
\text { sarana dan prasarana lalu lintas dan } \\
\text { angkutan jalan }\end{array}$ & $\begin{array}{l}\text { Hal ini cukup menarik untuk digarisbawahi, } \\
\text { karena tidak cukup jelas mengapa harus ada } \\
\text { pengaturan tersendiri dalam UU Lalu Lintas } \\
\text { dan Jalan Raya menyangkut sektor industri } \\
\text { dan pengembangan teknologi }\end{array}$ \\
\hline Pasal 302 & $\begin{array}{l}\text { Setiap orang yang mengemudikan } \\
\text { Kendaraan Bermotor Umum angkutan } \\
\text { orang yang tidak berhenti selain di tempat } \\
\text { yang telah ditentukan, mengetem, } \\
\text { menurunkan penumpang selain di tempat } \\
\text { pemberhentian, atau melewati jaringan } \\
\text { jalan selain yang ditentukan dalam izin } \\
\text { trayek sebagaimana dimaksud dalam } \\
\text { Pasal } 126 \text { dipidana dengan pidana } \\
\text { kurungan paling lama } 1 \text { (satu) bulan atau } \\
\text { denda paling banyak Rp250.000,00 (dua } \\
\text { ratus lima puluh ribu rupiah). }\end{array}$ & $\begin{array}{l}\text { Seberapa banyak sarana halte yang } \\
\text { disediakan pada satu trayek angkutan } \\
\text { umum. Dapat dilihat pada wilayah-wilayah } \\
\text { di daerah khususnya di luar Pulau Jawa }\end{array}$ \\
\hline Pasal 310 & $\begin{array}{l}\text { Terkait dengan kelalaian pengemudi } \\
\text { hingga mengakibatkan korban jiwa }\end{array}$ & $\mathrm{P}$ \\
\hline
\end{tabular}

Permasalahan kesadaran atau disiplin hukum masyarakat lebih berat dan kompleks dibandingkan dengan masalah substansi hukum, karena berkaitan dengan problema substansi hukum upaya yang dapat dilakukan lebih mudah yaitu melakukan revisi atau amandemen, atau apabila perubahan tersebut melebihi 50\%, maka dibuat UU yang baru. Namun, untuk menyelesaikan permasalahan kesadaran hukum warga masyarakat memang 
bukan masalah yang mudah, perlu dicari dahulu akar permasalahannya kemudian menentukan pola atau mekanisme penyuluhan hukum yang efektif dan efisien. Berkaitan dengan dengan hal ini, Soerjono Soekanto berdasarkan hasil penelitiannya berpendapat ada 4 (empat) indikator yang mempengaruhi tingkat kesadaran hukum atau kepatuhan hukum, yaitu: a. pengetahuan hukum; $b$. pengetahuan tentang isi hukum; c. sikap hukum; d. pola perikelakukan hukum.

Soerjono Soekanto dalam penelitiannya yang dilakukan terhadap 489 mahasiswa Fakultas Hukum UI terhadap UU Lalu Lintas menyimpulkan bahwa pengetahuan hukum tidak mempengaruhi secara positif maupun negatif terhadap tingkat kesadaran hukum. Hal ini berarti pengetahuan terhadap UU No. 22 Tahun 2009, tidak menjadi ukuran bahwa seseorang yang mengetahui UU tersebut tingkat kesadaran hukumnya lebih tinggi.

Pengetahuan terhadap isi hukum menyebabkan terjadinya kesadaran hukum tetapi sukar menentukan secara pasti derajat kepatuhan seperti apa yang dicapai dengan pengetahuan tersebut, karena tergantung pada teladan yang diberikan oleh pejabat hukum dan taraf kesempurnaan mekanisme pengawasan pelaksana peraturan. Sebagai contoh: seorang warga masyarakat akan cenderung mencontoh untuk tidak menggunakan helm pada saat berkendaraan karena melihat polisi juga tidak menunjukan keteladan untuk menggunakan helm. Contoh lain, seorang warga masyarakat pada pagi hari tidak menggunakan helm pada saat berkendaraan tetapi dibiarkan oleh petugas (polisi tidak melakukan pengawasan yang ketat dengan cara menegur). Berdasarkan kedua contoh tersebut, apabila terus menerus terjadi maka perbuatan tersebut akan "dianggap biasa" padahal merupakan pelanggaran hukum yang dapat dikenakan sanksi menurut UU No. 22 Tahun 2009.

Sikap hukum atau kecenderungan bertindak berkaitan erat dengan sikap fundamental (seperti meningkatnya umur, tingkat pendidikan, dan lamanya tinggal) dan sikap instrumental (pengetahuan tentang isi peraturan dan menonjolnya kepentingan pribadi). Seseorang yang bersikap fundamental akan bereaksi secara serta merta tanpa memperhitungkan untung ruginya bagi diri sendiri (tanpa didasarkan kepentingan pribadi). Sebaliknya seorang instrumentalis akan memperhitungkan keburukan-keburukan dan kebaikan-kebaikan suatu kaedah secara mantap (misalnya mematuhi hukum karena takut sanksi, atau ada petugas pengawas atau karena kebanyakan orang mematuhinya). Dengan demikian, kepatuhan masyarakat terhadap UU Lalu Lintas dan Angkutan Jalan pada umumnya disebabkan sikap fundamental yang tergantung pada meningkatnya usia, tingkat pendidikan, dan lamanya tinggal.

Pola perikelakuan hukum merupakan setiap perikelakuan teratur yang bertujuan untuk mencapai keserasian antara ketertiban dan kebebasan. Setiap perikelakuan yang sesuai dengan hukum merupakan salah satu ciri atau kriteria adanya kepatuhan atau ketaatan yang tinggi. Dugaan tersebut akan sesuai dengan kenyataan apabila ditelaah lebih lanjut megapa warga masyarakat berperikelakuan sesuai hukum, sehingga pola perikelakuan hukum merupakan hal yang identik denga kepatuhan hukum. Pola perikelakuan hukum merupakan kriterium kepatuhan hukum apabila warga masyarakat berperikelakuan tersebut, karena proses internalisasi yaitu hukum sesuai dengan nilai-nilai yang dianut oleh warga masyarakat. Hal ini disebabkan karena dengan berperikelakuan demikian, maka hukum benar-benar telah melembaga dan bahkan mendarah daging. Dengan demikian, pola perikelakuan hukum sangat mempengaruhi kepatuhan hukum ${ }^{32}$.

\section{PENUTUP}

Pemahaman terhadap isi Undang-undang No 22 Tahun 2009 Tentang Lalu Lintas dan Angkutan Jalan sulit diukur tingkat kesadaran hukumnya karena ada faktor lain yang mempengaruhi yaitu teladan dari pejabat dan mekanisme pengawasan ikut menentukan juga. Karena itu, untuk meningkatkan kesadaran hukum warga masyarakat tidak hanya kebijakan untuk mengadakan penyuluhan hukum saja tetapi juga disarankan teladan terutama dari para penegak hukum karena karakter budaya bangsa Indonesia yang bersifat "paternalistik". Selain itu, perlu mengefektifkan mekanisme pengawasan agar lebih komprehensif melalui KISS (Koordinasi, Integrasi, Simplikasi, dan Sinkronisasi). 


\section{DAFTAR CATATAN KAKI}

${ }^{1}$ Umi Laili dalam http://

download.portalgaruda.org/ article.php?

article $=183588$

$\&$ val $=6383 \&$ title $=$ KEBIJAKAN $\%$

20PENYULUHAN\%20HUKUM\%20\%20P

ADA\%20KANWIL\%20KEMENTERIAN\%

20HUKUM\%20DAN\%20HAM\%20KALIM

ANTAN\%20TIMUR. Diakses 20 Juli 2016,

${ }^{2}$ Ibid pukul $21.00 \mathrm{WIB}$.

${ }^{3}$ Penjelasan Umum Atas Undang-Undang Republik Indonesia Nomor 22 Tahun 2009 Tentang Lalu Lintas dan Angkutan Jalan.

${ }^{4}$ Ibid.

${ }^{5}$ Ibid

${ }^{6}$ Pasal 1 Angka 1 Peraturan Menteri Hukum dan HAM RI Nomor : M-01.PR.08.10 Tahun 2007 Tentang Perubahan atas Peraturan Menteri Hukum dan Hak Asasi Manusia RI Nomor : M-01.PR.08.10 Tahun 2006 Tentang Pola Penyuluhan Hukum Tentang Pola Penyuluhan Hukum

${ }_{8}^{7}$ Ibid, Pasal 1 Angka 2,

http://www.ferlianusgulo.web.id/2016/03/pe nyuluhan-hukum-yang-membuat.html

${ }^{9}$ Pasal 2 Peraturan Menteri Hukum dan HAM RI Nomor : M-01.PR.08.10 Tahun 2007 tentang Perubahan atas Peraturan Menteri Hukum dan Hak Asasi Manusia RI Nomor : M-01.PR.08.10 Tahun 2006, ibid.

${ }^{10}$ Lawrence M. Friedman, Hukum Amerika Sebuah Pengantar, PT Tata Nusa, Jakarta, 2001, hlm. 7-8.

${ }^{11}$ Esmi Warassih, Pranata Hukum Sebuah Telaah Sosiologis, PT Suryandaru Utama, 12 Semarang, 2005, hlm. 89

http://www.ferlianusgulo.web.id/2016/03/pe nyuluhan-hukum-yang-membuat. html. Dikses 22 Juli 2016, pukul 19.00 WIB.

${ }^{13}$ Bernard Arief Sidharta, Refleksi Tentang Struktur Ilmu Hukum, Sebuah Penelitian tentang Fundasi Kefilsafatan dan Sifat Keilmuan Ilmu Hukum Sebagai Landasan Pengembangan Ilmu Hukum Nasional Indonesia, CV Mandar Maju, Bandung, 2000, hlm. 203. Lihat juga http://www.ferlianusgulo.web.id/2016/03/pe nyuluhan-hukum-yang-membuat.html, loc.cit.
${ }^{14}$ Sjachran Basah, Tiga Tulisan Tentang Hukum, CV Armico, Bandung, 1986, hlm. 8-9. Lihat juga http://www.ferlianusgulo.web.id/2016/03/pe nyuluhan-hukum-yang-membuat.html. Diakses 30 Juli 2016, pukul 22.09.WIB

${ }^{15}$ Soerjono Soekanto, Kesadaran Hukum dan Kepatuhan Hukum, CV Rajawali, Jakarta 1982, hlm 230.

${ }^{16}$ Ibid, hm 225-226.

${ }^{17}$ Soerjono Soekanto, Ibid, hlm 234.

${ }^{18}$ Soerjono Soekanto sebagaimana dikutip oleh http:// www.ferlianusgulo. web.id/ 2016/03/ penyuluhan-hukum-yang-membuat.html, ibid.

${ }^{19}$ Sudjito, Critical Legal Stidies (CLS) dan Hukum Progresif Sebagai Alternatif Dalam Reformasi Hukum Nasional dan Perubahan Kurikulum Pendidikan Hukum, Jurnal Ultimatum Sekolah Tinggi Ilmu Hukum Iblam, Vol. 2, Edisi September, 2008, hlm. 3 sebagaimana dikutip oleh http://fh.uisu.ac.id/peranan-budaya-hukumdalam-perspektif-pembangunan-hukumnasional/. Diakses 15 Agustus 2016,pukul 21.00 .

${ }^{20}$ Ibid.

${ }^{21}$ Lili Rasyidi dan I.B. Wyasa Putra, Hukum Sebagai Suatu Sistem, PT Remaja Rosdakarya, Bandung, 1993, hlm 126.

${ }^{22}$ Nurul Huda, Penyuluhan Huk um dan Hak Asasi Manusia Sebuah Ilmu (Kajian Filsafat Ilmu), dalam http://www.rudyct.com/PPS702$\mathrm{ipb} / 04212 /$ nurul_huda.htm. Diakses 4 Agustus 2016, pukul 19.00 WIB.

${ }^{23}$ Laurensius Arliman S, Kewajiban Notaris Dalam Pemberian Penyuluhan Hukum Kepada Masyarakat Berdasarkan UndangUndang Nomor 2 Tahun 2014 Tentang Perubahan Atas Undang-Undang Nomor 30 Tahun 2004 Tentang Jabatan Notaris,file://C:/ Users/user/AppData/ Local/Temp/Laurensia\% 20Arliman $\% 20 \mathrm{~S} \%$ 20Kewajiban $\% 20$ Notaris $\% 20$ dalam $\% 20 \mathrm{Pem}$ berian\%20Penyuluhan\%20Hukum.pdf. Diakses 6 Agustus 2016,pukul 21.00 WIB.

${ }^{24} \mathrm{http} / / / \mathrm{www}$. ferlianusgulo.web.id/2016/03/ penyuluhan-hukum-yang-membuat. html, ibid.

${ }^{25}$ Anas Sudijono, sebagaimana dikutip oleh http:// digilib. uinsby.ac.id/872/5/ 


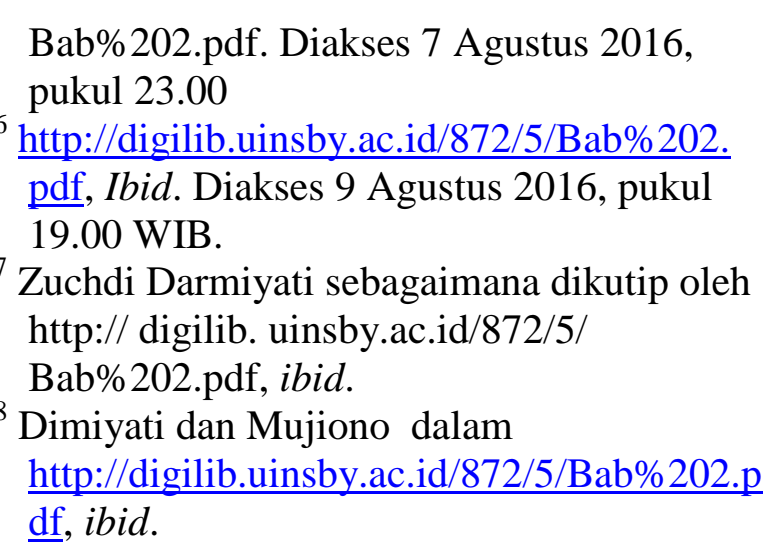

\section{DAFTAR PUSTAKA}

Bernard Arief Sidharta, (2000), Refleksi Tentang Struktur Ilmu Hukum, Sebuah Penelitian tentang Fundasi Kefilsafatan dan Sifat Keilmuan Ilmu Hukum Sebagai Landasan Pengembangan Ilmu Hukum Nasional Indonesia, Bandung: CV. Mandar Maju.

Esmi Warassih, (2005), Pranata Hukum Sebuah Telaah Sosiologis, Semarang: PT Suryandaru Utama.

Lawrence M. Friedman, (2001), Hukum Amerika Sebuah Pengantar, Jakarta: PT Tata Nusa.

Lili Rasyidi dan I.B. Wyasa Putra, (1993), Hukum Sebagai Suatu Sistem, Bandung: PT Remaja Rosdakarya.

Sjachran Basah, (1986), Tiga Tulisan Tentang Hukum, Bandung: CV Armico.

Soerjono Soekanto, (1982), Kesadaran Hukum dan Kepatuhan Hukum, Jakarta: CV Rajawali.

(1986), Beberapa Cara dan Mekanisme dalam Penyuluhan Hukum, Jakarta: Pradnya Paramita.

Undang-Undang Republik Indonesia Nomor 22, Tahun 2009, Tentang Lalu Lintas dan Angkutan Jalan.

Peraturan Menteri Hukum dan HAM RI Nomor : M-01.PR.08.10 Tahun 2007 Tentang Perubahan atas Peraturan Menteri Hukum dan Hak Asasi Manusia RI Nomor : M01.PR.08.10 Tahun 2006 Tentang Pola Penyuluhan Hukum Tentang Pola Penyuluhan Hukum.

Nofiardi, (2015), Membangun Hukum Indonesia Yang Progresif, Jurnal Advokasi, Vol. 6 No. 1 Juni-Desember 2015.
${ }^{29}$ Ibid.

${ }^{30}$ Ibid.

${ }^{31}$ Edy Halomoan Gurnin, dalam http://www. bantuanhukum.or.id/ web/ implementasiundang-undang-nomor-22-tahun-2009tentang-lalu-lintas-dan-angkutan-jalan-raya/. Diakses 9 Agustus 2016, pukul 20.00 WIB.

${ }^{32}$ Soerjono Soekanto, op.cit, hlm 247.

Sudjito, (2008), Critical Legal Stidies (CLS) dan Hukum Progresif Sebagai Alternatif Dalam Reformasi Hukum Nasional dan Perubahan Kurikulum Pendidikan Hukum, Jurnal Ultimatum Sekolah Tinggi Ilmu Hukum Iblam, Vol. 2, Edisi September, 2008.

Anas Sudijono, sebagaimana dikutip oleh http:// digilib. uinsby.ac.id/872/5/ Bab\%202.pdf. Diakses 7 Agustus 2016, pukul 23.00.

Dimiyati dan Mujiono dalam http://digilib.uinsby.ac.id/872/5/Bab\%202 .pdf. Diakses 9 Agustus 2016, pukul 19.00 WIB.

Edy Halomoan Gurnin, dalam http://www. bantuanhukum.or.id/ web/ implementasiundang-undang-nomor-22-tahun-2009tentang-lalu-lintas-dan-angkutan-jalanraya/. Diakses 9 Agustus 2016, pukul 20.00 WIB.

http://www.ferlianusgulo.web.id/2016/03/peny uluhan-hukum-yang- membuat. html. Dikses 22 Juli 2016, pukul 19.00 WIB. http://fh.uisu.ac.id/peranan-budaya-hukumdalam-perspektif-pembangunan-hukumnasional/ Diakses 15 Agustus 2016,pukul 21.00 .

Laurensius Arliman S, (2004), Kewajiban Notaris Dalam Pemberian Penyuluhan Hukum Kepada Masyarakat Berdasarkan Undang-Undang Nomor 2 Tahun 2014 Tentang Perubahan Atas Undang-Undang Nomor 30 Tahun 2004 Tentang Jabatan Notaris, Jurnal Advokasi Vol. 4 No. 2 September 2013 file://C:/ Users/ user/AppData/ Local/Temp/ Laurensia\% 20 Arliman $\% 20$ S\%20 Kewajiban\% 20Notaris $\% 20$ dalam \% 20Pemberian\% 
14 Sudjana, Penyuluhan hukum dalam upaya peningkatan kesadaran hukum berlalulintas.....

20 Penyuluhan\%20 Hukum.pdf. Diakses 6 Agustus 2016,pukul 21.00 WIB.

Nurul Huda, Penyuluhan Hukum dan Hak Asasi Manusia Sebuah Ilmu (Kajian Filsafat Ilmu), dalam http://www.rudyct.com/PPS702$\mathrm{ipb/04212/nurul} \mathrm{huda.htm.} \mathrm{Diakses} 4$ Agustus 2016, pukul 19.00 WIB.
Umi Laili dalam http:// download. Portal garuda.org/article.php? article $=183588 \&$ val $=6383 \&$ title $=$ KEBIJAKAN\%20 PENYULUHAN $\% 20$ HUKUM\% $20 \% 20$ PADA\% 20 KANWIL\%20KEMENTERIAN\%20HU KUM\%20DAN\%20HAM\%20KALIMA NTAN\%20TIMUR. Diakses 20 Juli 2016, pukul 21.00 WIB. 